\title{
A new yeast genus, Tetrapisispora gen. nov.: Tetrapisispora iriomotensis sp. nov., Tetrapisispora nanseiensis sp. nov. and Tetrapisispora arboricola sp. nov., from the Nansei Islands, and reclassification of Kluyveromyces phaffii (van der Walt) van der Walt as Tetrapisispora phaffii comb. nov.
}

\author{
Kumiko Ueda-Nishimura and Kozaburo Mikata
}

Institute for Fermentation, Osaka 17-85, Juso-honmachi 2-chome, Yodogawa-ku, Osaka 532-8686, Japan
Author for correspondence: Kumiko Ueda-Nishimura. Tel: +8163006555 . Fax: +8163006814. e-mail: kumiueda@mb.infoweb.ne.jp

Keywords: ascomycetous yeast, Tetrapisispora gen. nov., 18S rRNA gene

\section{INTRODUCTION}

The genus Kluyveromyces comprises ascomycetous fermentation yeasts characterized by smooth ascospores liberated from the asci (van der Walt, 1965). Molnár et al. (1996) showed that members of Kluyveromyces are homogeneous for the coenzyme Q-6. Poncet (1973) identified three phenetic lines by factor analysis. DNA base composition data (Vaughan-Martini \& Martini, 1987) were compatible with the existence of three groups. The three devised groups, having low, medium and high DNA G + C contents, correspond respectively to groups A, B and $C$ of Poncet (1973). In the fourth edition of 'The Yeasts' (Lachance, 1998), 15 species of Kluyveromyces

Abbreviation: PFGE, pulsed-field gel electrophoresis.

The DDBJ accession numbers for the 185 rDNA sequences reported in this paper are AB016506-AB016509. are shown and the genus is divided into the three groups. Group A comprises Kluyveromyces africanus, Kluyveromyces bacillisporus, Kluyveromyces blattae, Kluyveromyces delphensis, Kluyveromyces lodderae, Kluyveromyces phaffii, Kluyveromyces polysporus and Kluyveromyces yarrowii, species lacking in ethylamine and L-lysine assimilation, and groups $\mathrm{B}$ and $\mathrm{C}$ are made up of species able respectively to assimilate ethylamine and L-lysine strongly. The group-A species are phenetically homogeneous by many criteria (Poncet, 1973; Kock et al., 1988). In view of the ascospore numbers and ploidy of natural isolates, Naumov (1987) proposed the reclassification of $K$. phaffii in a separate genus.

Previous phylogenetic analyses (Cai et al., 1996; James et al., 1997) showed that the genus Kluyveromyces is not monophyletic and that species of this genus are intermixed with members of other genera, particularly Saccharomyces and Zygosaccharomyces. Groups B 
and $\mathrm{C}$ of Kluyveromyces each constitute a monophyletic entity. $K$. blattae and $K$. phaffii of group A, which is phylogenetically heterogeneous, were found to form a distinct lineage and to display no specific association with the other species examined. Cai et al. (1996) proposed that both $K$. blattae and $K$. phaffi should be excluded from the genus Kluyveromyces. No other $K$. phaffii strain or phylogenetically related species has been isolated since the $K$. phaffi $i$ type strain was isolated from South African soil (van der Walt, 1963). For this reason, perhaps, $K$. phaffii has not been transferred to another genus.

In this study, three new species closely related to $K$. phaffii were isolated from Iriomote and Ishigaki Islands, in the subtropical zone in the south-west part of the Nansei Islands, and Yaku Island, in the temperate zone in the north-east part of the islands. A novel genus, Tetrapisispora gen. nov., is proposed in this paper to accommodate $K$. phaffi $i$ and the three new species.

\section{METHODS}

Yeast isolation and identification. Yeasts were isolated from soil, leaves and flowers using enrichment culture. Enrichment broth medium contained 5\% malt extract and $3 \%$ glucose and after autoclaving, its $\mathrm{pH}$ was adjusted to 3.7 and $50 \mathrm{mg}^{-1}$ each of penicillin, streptomycin and chloramphenicol were added to repress bacterial growth. A piece or spoonful of a sample of substrate was inoculated into $10 \mathrm{ml}$ medium in a $15-\mathrm{ml}$ screw-cap test tube and incubated at $17^{\circ} \mathrm{C}$ without shaking for isolation of fermentative yeast strains. On days 7 and 14 after inoculation, the fungal mat that appeared on the surface of the medium was removed and a loopful of the culture liquid was spread onto a YM agar plate. Yeast were identified by standard methods (van der Walt \& Yarrow, 1984).

Pulsed-field gel electrophoresis (PFGE). Agarose plugs containing yeast chromosomal DNA were prepared according to the method of Carle \& Olson (1985). The gel was $1 \%$ agarose (Agarose NA; Pharmacia) in $0.5 \times$ TBE buffer chilled at $14^{\circ} \mathrm{C}$. PFGE was performed using a CHEF DRII system (Bio-Rad) at $200 \mathrm{~V}$ for $15 \mathrm{~h}$ with a $60-70 \mathrm{~s}$ switchtime ramp and for $7 \mathrm{~h}$ with a 90-120 s switch-time ramp. After electrophoresis, the gel was stained with $0.5 \mathrm{mg}$ ethidium bromide $1^{-1}$ for $10 \mathrm{~min}$ at room temperature and successively destained in distilled water for times varying from $1 \mathrm{~h}$ up to $1 \mathrm{~d}$.

Major ubiquinone analysis. The major ubiquinone was determined by HPLC according to the method described by Nakagiri (1991).

Genotypic analysis. Genomic DNA was extracted and purified using the procedure of Holm et al. (1986). The $\mathrm{G}+\mathrm{C}$ content was determined by the HPLC method of Tamaoka \& Komagata (1984). DNA similarity was measured by the microplate-hybridization method described by Kaneko \& Banno (1991) and calculated as a mean of five measurements.

18S rDNA sequencing. 18S rDNA sequences were determined using the Thermo Sequenase fluorescent-labelled primer cycle sequencing kit with 7-deaza-dGTP (Amersham) following the manufacturer's protocol. For amplification of
18S rDNA, PCR (Saiki et al., 1988) was performed for 30 cycles of denaturation at $94{ }^{\circ} \mathrm{C}$ for $0.5 \mathrm{~min}$, annealing at $55^{\circ} \mathrm{C}$ for $0.5 \mathrm{~min}$ and extension at $72^{\circ} \mathrm{C}$ for $2.5 \mathrm{~min}$ with TaKaRa Taq DNA polymerase (Takara) using the primer pair 18-F (5'-ATCTGGTTGATCCTGCCAGT-3') and 18R (5'-GATCCTTCCGCAGGTTCACC-3'). Diluted PCR products were used as a template for sequencing and $5^{\prime}$ FITC-labelled primers were 400F (5'-TCCGGAGAGGGAGCCTGAGAAACG-3'), 550F (5'-GCAGCCGCGGTAATTCCAGC-3'), 950F (5'-TCAAGAACGAAAGTTAGGGG-3'), 1200F (5'-AAAGGAATTGACGGAAGGGC-3'), 1300F (5'-TTGGTGGAGTGATTTGTCTG-3'), $1500 \mathrm{~F}$ (5'-GATGCCCTTAGACGTTCTGG-3') and 18-F for the sense strand and 400R (5'-TTCTCAGGCTCCCTCTCCGG-3'), 550R (5'-GAATTACCGCGGCTGCTGGC-3'), 950R (5'-TCCCCTAACTTTCGTTCTTG-3'), 1200R ( $5^{\prime}$-GGTGCCCTTCCGTCAATTCC-3'), 1300R (5' AGACAAATCACTCCACCAAC-3'), 1500R (5'-CCAGAACGTCTAAGGGCATCACAG-3') and 18-R for the reverse strand.

Phylogenetic analysis. Sequence data were manually aligned to various $18 \mathrm{~S}$ rDNA sequences of representatives of related genera obtained from GenBank. Positions that could not be compared among all sequences, corresponding to unknown bases, deletions and insertions, and regions difficult to align between each strain and outgroup were omitted from the phylogenetic analysis. A phylogenetic tree was constructed by Kimura's two-parameter method (Kimura, 1980) and the neighbour-joining method (Saitou \& Nei, 1987) using CLUSTAL W. Bootstrap values (Felsenstein, 1985) were calculated from 1000 replicates.

\section{RESULTS}

\section{Morphology and physiology of isolated strains}

Seven strains were isolated from soil, leaves of mangrove and flowers of back-mangrove (Table 1). In all isolates, asci arose directly from diploid cells and one to four oval or reniform ascospores were formed. The spores of strain U97-101-2 ${ }^{\mathrm{T}}$ were liberated from the ascus soon after formation and tended to agglutinate, whereas in the other strains, asci were persistent (Fig. 1). As monosporic cultures could sporulate, they were judged to be homothallic. In their physiological characters, the seven isolates were similar to $K$. phaffi, isolated from South African soil (van der Walt, 1963): fermentation of glucose and galactose, growth on glucose, galactose and glycerol and no utilization of most other compounds.

\section{Electrophoretic karyotypes of the isolates}

Chromosomal DNA banding patterns of the isolates were examined by PFGE (Fig. 2). All seven isolates showed most of the chromosomes displayed in a wide range of sizes $(2 \cdot 0-0 \cdot 2 \mathrm{Mb})$, in a similar way to Saccharomyces cerevisiae. The pattern of isolate Yk$305 \mathrm{a} 2$ from Yaku Island was similar to that of isolate U96-107-4 ${ }^{\mathrm{T}}$ from Ishigaki Island. Those of isolates U97-412-1 ${ }^{\mathrm{T}}$, U97-412-3, U97-436-2 and U97-437-2 were also similar to each other. However, slight differences were found within each of these groups. 
Table 1. Isolated strains and their origins

\begin{tabular}{|c|c|c|c|}
\hline \multicolumn{2}{|c|}{ Strain } & \multirow[t]{2}{*}{ Sample material } & \multirow[t]{2}{*}{ Locality } \\
\hline Original no. & IFO no. & & \\
\hline U97-101-2 & $10929^{x}$ & Soil & Iriomote Island \\
\hline U96-107-4 & $10899^{\mathrm{T}}$ & Soil & Ishigaki Island \\
\hline Yk-305a2 & 1883 & Soil & Yaku Island \\
\hline U97-412-1 & $10925^{\mathrm{T}}$ & Flower of Elaeocarpus decipiens & Iriomote Island \\
\hline U97-412-3 & 10926 & Flower of Elaeocarpus decipiens & Iriomote Island \\
\hline U97-436-2 & 10927 & Leaf of Bruguiera conjugata & Iriomote Island \\
\hline U97-437-2 & 10928 & Leaf of Rhizophora mucronata & Iriomote Island \\
\hline
\end{tabular}
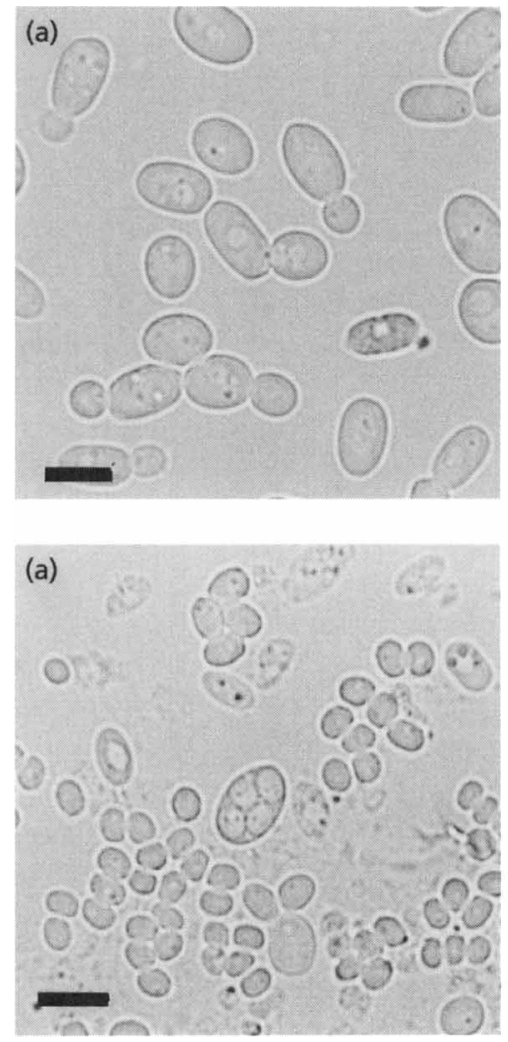
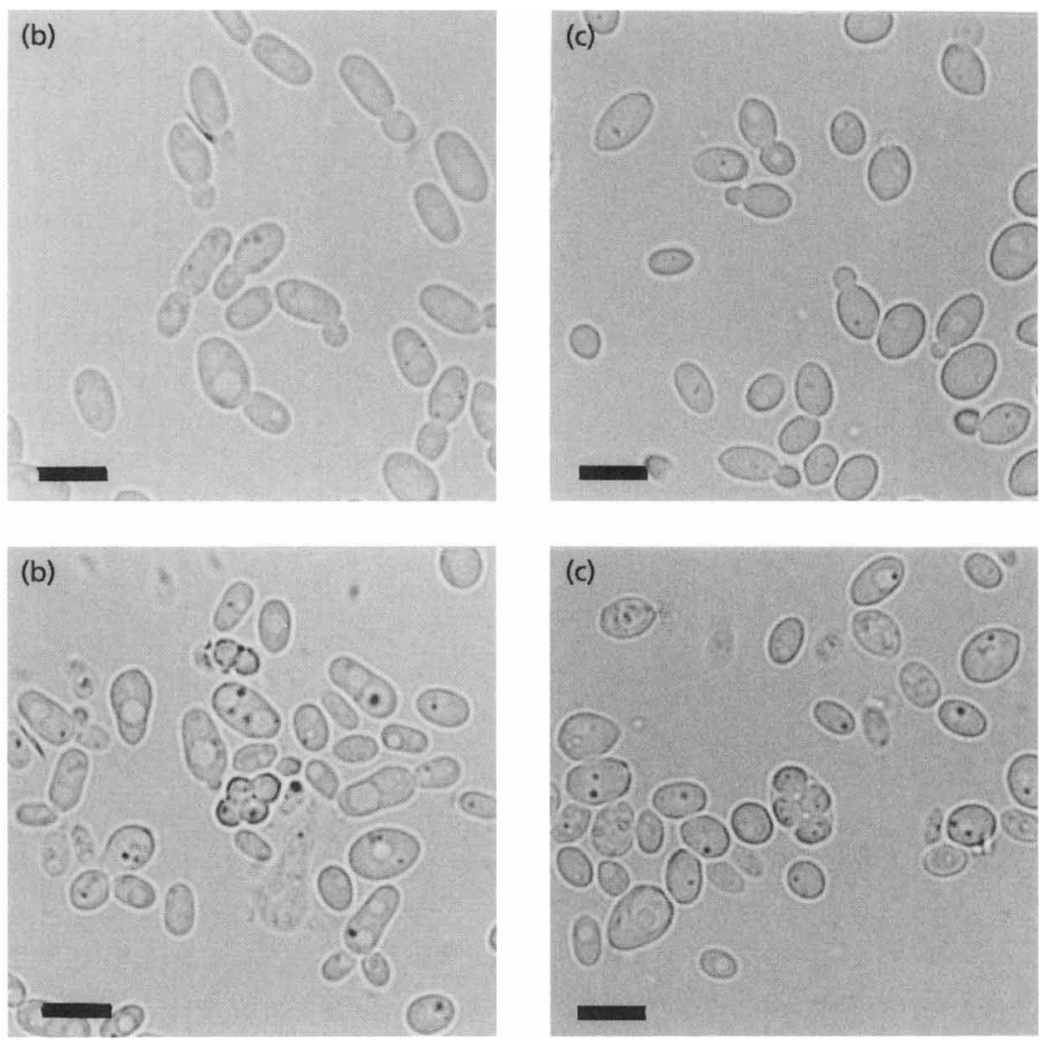

Fig. 1. Photomicrographs of vegetative cells on YPD broth (upper) and asci on potassium acetate agar (lower). (a) U97$101-2^{\top}$ (T. iriomotensis IFO $\left.10929^{\top}\right)$, (b) U96-107-4 $\left(T\right.$. nanseiensis IFO 10899 $\left.{ }^{\top}\right)$, (c) U97-412-1 ${ }^{\top}$ ( $T$. arboricola IFO $\left.10925^{\top}\right)$. Bars, $5 \mu \mathrm{m}$.

U97-412-1 ${ }^{\mathrm{T}}$ and U97-412-3 were thought to originate from an identical strain, since they were isolated from the same sample. The pattern of U97-412-3 had an extra, minor band between the first and second major bands in comparison with that of U97-412-1 ${ }^{\mathrm{T}}$, suggesting that these isolates were related but not identical. The pattern of U97-101-2 ${ }^{\mathrm{T}}$ was unlike all the others. Therefore, the seven isolates were categorized into three groups by their PFGE patterns, which differed also from those of type strains of $K$. phaffii and all other known Kluyveromyces and Saccharomyces species (data not shown).

\section{DNA base composition and DNA-DNA hybridization}

The $\mathrm{G}+\mathrm{C}$ contents of the DNA of all isolates were $30.4-32.3 \mathrm{~mol} \%$, close to the $32.7 \mathrm{~mol} \%$ of K. phaffii. To survey species identities of isolates, their DNA 


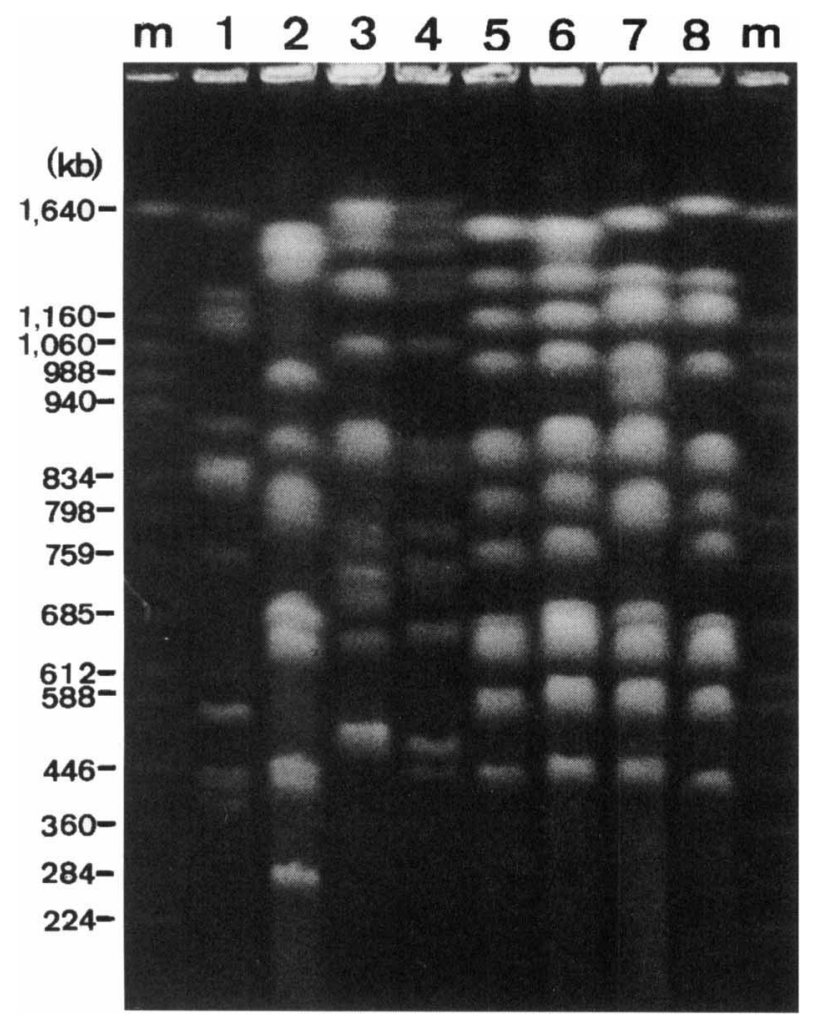

Fig. 2. PFGE analysis of $K$. phaffii and isolates. Lanes: $m, S$. cerevisiae SH 964 as molecular size marker; $1, K$. phaffii IFO $1672^{\top} ; 2$, U97-101-2 ${ }^{\top}$ (T. iriomotensis IFO $\left.10929^{\top}\right)$; 3, Yk-305a2 ( $T$. nanseiensis IFO 1883); 4, U96-107-4 ${ }^{\top}$ ( $T$. nanseiensis IFO $\left.10899^{\top}\right)$; 5, U97-412-1 ${ }^{\top}\left(T\right.$. arboricola IFO $\left.10925^{\top}\right)$; 6, U97-412-3 ( $T$. arboricola IFO 10926); 7, U97-436-2 ( $T$. arboricola IFO 10927); 8, U97-437-2 (T. arboricola IFO 10928).

similarity values to each other and to $K$. phaffi $i$ were examined by the microplate-hybridization method. The results are shown in Table $2 . K$. phaffii type strain IFO $1672^{\mathrm{T}}$ and isolate U97-101-2 ${ }^{\mathrm{T}}$ showed low simi-
Table 3. Identities and numbers of substitutions between $18 \mathrm{~S}$ rDNA sequences

The upper-right figures show percentage sequence identity; lower-left figures show numbers of base substitutions. Boldface type indicates isolates from the same species.

\begin{tabular}{|c|c|c|c|c|c|c|}
\hline \multirow[t]{2}{*}{ Strain } & \multirow[t]{2}{*}{ IFO no. } & \multicolumn{5}{|c|}{$\begin{array}{c}\text { Identities }(\%) \text { and numbers of } \\
\text { substitutions }\end{array}$} \\
\hline & & 1 & 2 & 3 & 4 & 5 \\
\hline 1. K. phaffii & $1672^{\mathrm{T}}$ & - & $99 \cdot 5$ & $99 \cdot 5$ & $99 \cdot 4$ & $99 \cdot 5$ \\
\hline 2. U97-101-2 & $10929^{\mathrm{T}}$ & 8 & - & 99.5 & $99 \cdot 4$ & $99 \cdot 4$ \\
\hline 3. U96-107-4 & $10899^{\mathrm{T}}$ & 9 & 9 & - & 99.9 & $99 \cdot 8$ \\
\hline 4. $Y k-305 a 2$ & 1883 & 10 & 10 & 1 & - & $99 \cdot 8$ \\
\hline 5. U97-412-1 ${ }^{\mathrm{T}}$ & $10925^{\mathrm{T}}$ & 9 & 10 & 3 & 4 & - \\
\hline 6. U97-436-2 & 10927 & 9 & 10 & 3 & 4 & 0 \\
\hline 7. U97-437-2 & 10928 & 9 & 10 & 3 & 4 & $\mathbf{0}$ \\
\hline
\end{tabular}

larity to all tested strains. DNA similarity values of U96-107-4 ${ }^{\mathrm{T}}$ and Yk-305a2 were $79 \cdot 2$ and $97.0 \%$ and those of U97-412-1 $1^{\mathrm{T}}$ to U97-412-3, U97-436-2 and U97-437-2 were $99 \cdot 7,105 \cdot 2$ and $116 \cdot 6 \%$. These data showed that U96-107-4 and Yk-305a2 should be considered to be conspecific, as should U97-412-1 ${ }^{\mathrm{T}}$, U97-412-3, U97-436-2 and U97-437-2. The DNA similarity values of the isolates thus confirmed the three distinct groups revealed by PFGE patterns (Fig. 2).

\section{Phylogeny}

18S rDNA sequences of the isolates were determined by the direct method. Although U96-107-4 ${ }^{\mathrm{T}}$ from Ishigaki Island and Yk-305a2 from Yaku Island were the same species, a substitution was found between the

Table 2. Similarity and $G+C$ content of DNA of isolated strains

Hybridization was performed at $40^{\circ} \mathrm{C}$. Boldface type indicates isolates of the same species; ND, not determined.

\begin{tabular}{|c|c|c|c|c|c|c|c|}
\hline \multirow[t]{2}{*}{ Strain } & \multirow[t]{2}{*}{ IFO no. } & \multirow{2}{*}{$\begin{array}{c}G+C \text { content } \\
(\mathrm{mol} \%)\end{array}$} & \multicolumn{5}{|c|}{ DNA similarity $(\%)$} \\
\hline & & & 1 & 2 & 3 & 4 & 5 \\
\hline 1. K. phaffii & $1672^{\mathrm{T}}$ & $32 \cdot 7$ & 100 & $15 \cdot 6$ & $17 \cdot 9$ & $26 \cdot 9$ & $32 \cdot 6$ \\
\hline 2. U97-101-2 & $10929^{\mathrm{T}}$ & $32 \cdot 3$ & $33 \cdot 2$ & 100 & $24 \cdot 3$ & $35 \cdot 0$ & $30 \cdot 5$ \\
\hline 3. U96-107-4 & $10899^{\mathrm{T}}$ & $30 \cdot 4$ & $29 \cdot 4$ & $18 \cdot 8$ & 100 & 97.0 & $29 \cdot 9$ \\
\hline 4. $Y k-305 a 2$ & 1883 & $31 \cdot 2$ & $21 \cdot 6$ & $17 \cdot 8$ & 79.2 & 100 & $20 \cdot 5$ \\
\hline 5. U97-412-1 ${ }^{\mathrm{T}}$ & $10925^{\mathrm{T}}$ & $31 \cdot 2$ & $34 \cdot 2$ & $25 \cdot 4$ & $33 \cdot 3$ & $40 \cdot 1$ & 100 \\
\hline 6. U97-412-3 & 10926 & $31 \cdot 4$ & ND & $24 \cdot 1$ & ND & ND & 99.7 \\
\hline 7. U97-436-2 & 10927 & $32 \cdot 3$ & ND & $36 \cdot 7$ & ND & ND & 105.2 \\
\hline 8. U97-437-2 & 10928 & $32 \cdot 0$ & ND & $37 \cdot 7$ & ND & ND & 116.6 \\
\hline 9. S. cerevisiae & $10217^{\mathrm{T}}$ & $38 \cdot 0$ & ND & $19 \cdot 1$ & ND & ND & $29 \cdot 7$ \\
\hline
\end{tabular}




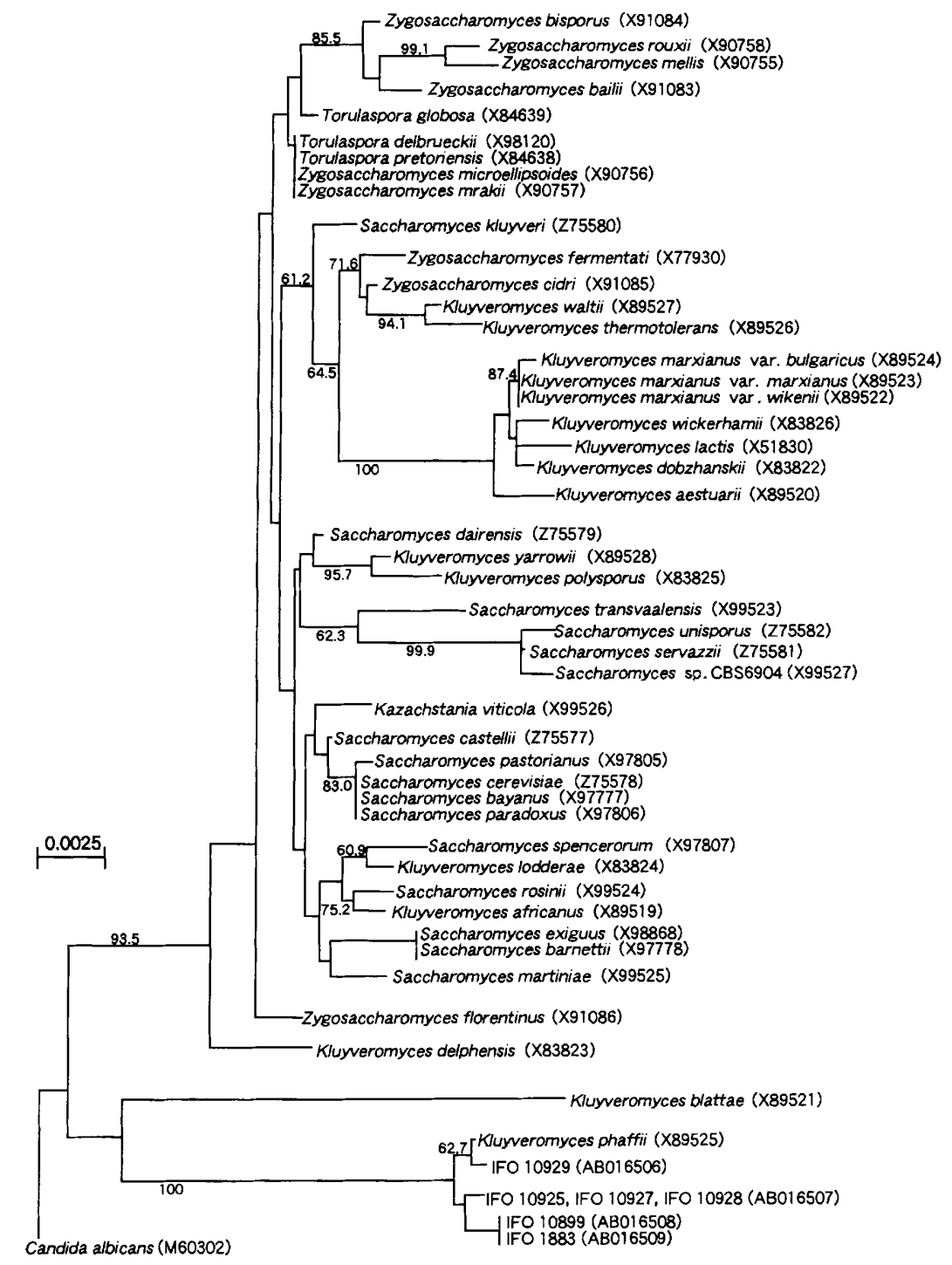

Fig. 3. Phylogenetic tree showing the relationship of the strains isolated to species of the genera Kluyveromyces, Saccharomyces, Zygosaccharomyces and Torulaspora. The tree is based on 185 rDNA sequence data and was constructed by using the neighbour-joining method. Bootstrap values were calculated from 1000 trees and values $<60 \%$ were omitted. GenBank, EMBL and DDBJ accession numbers are shown in parentheses. Bar, sequence dissimilarity of $0.25 \%$. The outgroup species was Candida albicans.
18S rDNA sequences of the two isolates (Table 3). This was located in a variable region that was ignored in the analysis because of difficulty of alignment among all used sequences, and thus no phylogenetic distinction could be detected. The sequences for U97-412-1 ${ }^{\mathrm{T}}$, U97-436-2 and U97-437-2 from Iriomote Island were identical. The three isolated species and $K$. phaffii were found to be closely related to one another, with a $100 \%$ bootstrap value and levels of $18 \mathrm{~S}$ rDNA sequence identity of $>99.4 \%$ (Table 3 ), and were phylogenetically separate from the other Kluyveromyces species and non-Kluyveromyces species examined (Fig. 3). Their closest relative was K. blattae, which also formed a distinct line of descent that was quite separate from the other species.

DNA-DNA hybridization tests suggested that the new isolates and $K$. phaffii represented three different species. On the basis of these facts, the novel genus Tetrapisispora gen. nov. is proposed. Differential characteristics for Tetrapisispora species are listed in Table 4.

\section{Latin diagnosis of Tetrapisispora gen. nov.}

Genus ad Saccharomycetaceae pertinens. Cellulae ellipsoideae, ovoideae vel cylindricae, per gemmationem multilateralem reproducentes. Pseudomycelium nullum. Genus homothallicum et diploideum. Asci per transformationem cellularum vegetativarum diploidearum et rumpuntur aut non rumpuntur, 1-4 ascosporas continentes. Ascosporae ovoidae aut reniformes. Nitras kalicus, ethylaminum, lysinum nec cadaverinum non assimilantur. Diazonium caerulian B non respondens.

Systema coenzymatis Q-6 adest. $\mathrm{G}+\mathrm{C}$ acidi deoxyribonucleati 30-33 mol\%. Species typica: Tetrapisispora phaffi (van der Walt) Ueda-Nishimura et Mikata comb. nov.

\section{Description of Tetrapisispora Ueda-Nishimura et Mikata gen. nov.}

Tetrapisispora (Te.tra.pi.si.spo'ra. G. pref. tetra four; L. n. pisi pea; L. fem. n. spora spore; M.L. n. Tetrapisispora four pea spores). 
Table 4. Distinguishing characteristics of Tetrapisispora species

$+\mathrm{s}$, Slow growth; +w, weak growth.

\begin{tabular}{|lcccc|}
\hline Characteristic & T. phaffii & T. iriomotensis & T. nanseiensis & T. arboricola \\
\hline Assimilation of: & & & & \\
$\quad$ Trehalose & - & - & - & + \\
$\quad$ Gluconate & + & + & + & $-/+$ \\
Growth on vitamin-free medium & - & $+\mathrm{w}$ & - & - \\
Growth on 0.01\% cycloheximide & - & - & $+\mathrm{S} /-$ & - \\
Growth on $10 \% \mathrm{NaCl}+5 \%$ & - & $+\mathrm{s}$ & - & $+\mathrm{S}$ \\
glucose & + & + & - & - \\
Ascus deliquescence & + & & & \\
\hline
\end{tabular}

The genus belongs to the Saccharomycetaceae. Cells are ellipsoid, ovoid to cylindrical, reproducing by multilateral budding. No pseudomycelium is formed. The genus is homothallic and diploid. Asci arise by transformation of diploid vegetative cells and are ruptured or persistent on maturation, containing 1-4 ascospores. Ascospores are ovoid to reniform and smooth. Glucose and galactose are fermented vigorously. Glucose, galactose and glycerol are assimilated. Nitrate, ethylamine, lysine and cadaverine are not assimilated. The diazonium blue $\mathrm{B}$ reaction is negative. Ubiquinone system is Q-6. G+C content of DNA is $30-33 \mathrm{~mol} \%$.

The type species is Tetrapisispora phaffii (van der Walt) Ueda-Nishimura et Mikata comb. nov. [basionym Fabospora phaffii van der Walt (1963)]. Synonyms: Kluyveromyces phaffii (van der Walt) van der Walt (1965) nom. inval.; Kluyveromyces phaffii (van der Walt) van der Walt (1971). The type strain of Tetrapisispora phaffii is CBS $4417^{\mathrm{T}}$ (= IFO $1672^{\mathrm{T}}$, $=$ ATCC $24235^{\mathrm{T}}$, =NRRL Y $-8282^{\mathrm{T}}$ ), isolated by van der Walt (1963) from soil. Other species accepted in the genus are Tetrapisispora iriomotensis sp. nov., Tetrapisispora nanseiensis sp. nov. and Tetrapisispora arboricola sp. nov.

\section{Latin diagnosis of Tetrapisispora iriomotensis sp. nov.}

In medio liquido cum glucoso et peptono et extracto levidinis post dies 2 ad $24^{\circ} \mathrm{C}$, cellulae ovoideae vel ellipsoideae, $2 \cdot 0-5 \cdot 0 \times 5 \cdot 0-8.0 \mu \mathrm{m}$, singulae aut binae, per gemmationem multilateralem reproducentes. Cultura in agaro cum glucoso, peptono et extracto levidinis post unum mensem ad $24^{\circ} \mathrm{C}$, butyrosa, glabra, nitida et eburnea. Pseudomycelium nullum. Asci per transformationem cellularum vegetativarum diploidearum, 1-4 ascosporas continentes. Ascosporae ovoidae aut reniformes. Ascosporae ex ascis liberantur et agglutinant.

Glucosum et galactosum fermentantur, at non Lsorbosum, maltosum, sucrosum, cellobiosum, trehalo- sum, lactosum, mellibiosum, raffinosum nec D-xylosum. Glucosum, galactosum, glycerolum, D-glucono-1,5-lactonum et gluconicum assimilantur, at non L-sorbosum, maltosum, sucrosum, cellobiosum, trehalosum, lactosum, melibiosum, raffinosum, melezitosum, inulinum, amylum, D-xylosum, L-arabinosum, D-arabinosum, Dribosum, L-rhamnosum, ethanolum, erythritolum, ribitolum, galactitolum, D-mannitolum, D-glucitolum, $\alpha$ methyl D-glucosidum, salicinum, acidum lacticum, acidium succinicum, acidium citricum, inositolum, glucosaminum nec arbutinum.

Nitras kalicus, ethylaminum, lysinum nec cadaverinum non assimilantur. Exiguum crescit sine vitaminis. Non crescere potest in $0.01 \%$ cycloheximido. Lente crescere potest in $10 \% \mathrm{NaCl} / 5 \%$ glucoso. Augmentum in $34{ }^{\circ} \mathrm{C}$. Diazonium caerulian B non respondens. $\mathrm{G}+\mathrm{C}$ acidi deoxyribonucleati $32 \mathrm{~mol} \%$ per HPLC. Systema coenzymatis Q-6 adest.

Typus depositus in collectione Institute for Fermentation, Osaka, Japonia (IFO 10929 $)$.

\section{Description of Tetrapisispora iriomotensis sp. nov.}

Tetrapisispora iriomotensis (i.ri.o.mo.ten'sis. L. adj. iriomotensis pertaining to Iriomote Island, Japan, where the yeast was originally isolated).

In YPD broth, after $48 \mathrm{~h}$ growth at $24^{\circ} \mathrm{C}$, the cells were ovoid to ellipsoidal and $2 \cdot 0-5 \cdot 0 \times 5 \cdot 0-8 \cdot 0 \mu \mathrm{m}$, single or in pairs. Sediment is present. Budding is multipolar. After 1 month at $24^{\circ} \mathrm{C}$, YPD agar streak culture is butyrous, smooth, glistening and creamcoloured. Branching hyphae or pseudohyphae are not formed in Dalmau plate cultures on corn meal agar. Oval asci containing $1-4$ ovoid to reniform ascospores are formed directly from diploid cells after incubation for 1 week at $24^{\circ} \mathrm{C}$ on potassium acetate agar, YM agar and cornmeal agar. The ascospores are liberated from the ascus soon after formation and tend to agglutinate.

Glucose and galactose are fermented. L-Sorbose, maltose, sucrose, cellobiose, trehalose, lactose, meli- 
biose, raffinose and D-xylose are not fermented. The following carbon compounds are assimilated: glucose, galactose, glycerol, D-glucono-1,5-lactone and gluconate. No growth occurs on L-sorbose, maltose, sucrose, cellobiose, trehalose, lactose, melibiose, raffinose, melezitose, inulin, starch, D-xylose, L-arabinose, Darabinose, D-ribose, L-rhamnose, ethanol, erythritol, ribitol, galactitol, D-mannitol, D-glucitol, $\alpha$-methyl Dglucoside, salicin, DL-lactate, succinate, citrate, inositol, glucosamine or arbutin. The following nitrogen compounds are not assimilated: nitrate, ethylamine, lysine and cadaverine. Weak growth occurs in vitaminfree medium. No growth occurs in the presence of $0.01 \%$ cycloheximide. Slow growth occurs in the presence on $10 \% \mathrm{NaCl} / 5 \%$ glucose. Growth occurs at $34{ }^{\circ} \mathrm{C}$, but not at $37^{\circ} \mathrm{C}$. The diazonium blue $\mathrm{B}$ reaction is negative. Production of starch-like substances is negative. $\mathrm{G}+\mathrm{C}$ content of DNA is $32 \mathrm{~mol} \%$ by HPLC. Ubiquinone system is Q-6.

The type strain U97-101-2 ${ }^{\mathrm{T}}$ was isolated in July 1997 from soil in Ootomi, Iriomote Island, Japan. Cultures of the type strain U97-101-2 ${ }^{\mathrm{T}}\left(=\mathrm{IFO} 10929^{\mathrm{T}}\right.$ ) have been deposited in the culture collection of the Institute for Fermentation, Osaka, Japan.

\section{Latin diagnosis of Tetrapisispora nanseiensis sp. nov.}

In medio liquid cum glucoso, peptono et extracto levidinis post dies 2 ad $24^{\circ} \mathrm{C}$, cellulae ovoideae vel cylindricae, 1.0-3.0 $\times 3 \cdot 0-6.0 \mu \mathrm{m}$, singulae aut binae, per gemmationem multilateralem reproducentes. Cultura in agaro cum glucoso, peptono et extracto levidinis post unum mensem ad $24{ }^{\circ} \mathrm{C}$, butyrosa, glabra, nitida et eburnea. Pseudomycelium nullum. Asci per transformationem cellularum vegetativarum diploidearum, 1-4 ascosporas continentes. Ascosporae ovoideae. Asci non rumpuntur.

Glucosum et galactosum fermentantur, at non L-sorbosum, maltosum, sucrosum, cellobiosum, trehalosum, lactosum, mellibiosum, raffinosum nec D-xylosum. Glucosum, galactosum, glycerolum, D-glucono-1,5lactonum et gluconicum assimilantur, at non Lsorbosum, maltosum, sucrosum, cellobiosum, trehalosum, lactosum, melibiosum, raffinosum, melezitosum, inulinum, amylum, D-xylosum, L-arabinosum, D-arabinosum, D-ribosum, L-rhamnosum, ethanolum, erythritolum, ribitolum, galactitolum, D-mannitolum, Dglucitolum, $\alpha$-methyl D-glucosidum, salicinum, acidum lacticum, acidium succinicum, acidium citricum, inositolum, glucosaminum nec arbutinum.

Nitras kalicus, ethylaminum, lysinum nec cadaverinum non assimilantur. Non crescit sine vitaminis. Exiguum crescere potest in $0.01 \%$ cycloheximido. Non crescere potest in $10 \% \mathrm{NaCl} / 5 \%$ glucoso. Augmentum in $34{ }^{\circ} \mathrm{C}$. Diazonium caerulian $\mathrm{B}$ non respondens. $\mathrm{G}+\mathrm{C}$ acidi deoxyribonucleati $30 \mathrm{~mol} \%$ per HPLC. Systema coenzymatis Q-6 adest.

Typus depositus in collectione Institute for Fermentation, Osaka, Japonia (IFO $10899^{\mathrm{T}}$ ).

\section{Description of Tetrapisispora nanseiensis sp. nov.}

Tetrapisispora nanseiensis (nan.se.i.en'sis. L. adj. nanseiensis pertaining to the Nansei Islands in Japan, where the yeasts were originally isolated).

In YPD broth, after $48 \mathrm{~h}$ of growth at $24^{\circ} \mathrm{C}$, the cells were ovoid to cylindrical and $1.0-3.0 \times 3 \cdot 0.6 \cdot 0 \mu \mathrm{m}$, single or in pairs. Sediment is present. Budding is multipolar. After 1 month at $24^{\circ} \mathrm{C}$, YPD agar streak culture is butyrous, smooth, glistening and creamcoloured. Branching hyphae or pseudohyphae are not formed in Dalmau plate cultures on corn meal agar. Ovoid asci containing 1-4 oval ascospores are formed directly from diploid cells after incubation for 1 week at $24^{\circ} \mathrm{C}$ on potassium acetate agar, YM agar and cornmeal agar. Asci are persistent.

Glucose and galactose are fermented. L-Sorbose, maltose, sucrose, cellobiose, trehalose, lactose, melibiose, raffinose and D-xylose are not fermented. The following carbon compounds are assimilated: glucose, galactose, glycerol, D-glucono-1,5-lactone and gluconate. No growth occurs on L-sorbose, maltose, sucrose, cellobiose, trehalose, lactose, melibiose, raffinose, melezitose, inulin, starch, D-xylose, L-arabinose, D-arabinose, D-ribose, L-rhamnose, ethanol, erythritol, ribitol, galactitol, D-mannitol, D-glucitol, $\alpha$ methyl D-glucoside, salicin, DL-lactate, succinate, citrate, inositol, glucosamine or arbutin. The following nitrogen compounds are not assimilated: nitrate, ethylamine, lysine and cadaverine. No growth occurs in vitamin-free medium. Slow growth occurs in the presence of $0.01 \%$ cycloheximide, but not $0.1 \%$. No growth occurs in the presence on $10 \% \mathrm{NaCl} / 5 \%$ glucose. Growth occurs at $34{ }^{\circ} \mathrm{C}$, but not at $37^{\circ} \mathrm{C}$. The diazonium blue $\mathrm{B}$ reaction is negative. Production of starch-like substances is negative. $\mathrm{G}+\mathrm{C}$ content of DNA is $30 \mathrm{~mol} \%$ by HPLC. Ubiquinone system is Q-6.

Strain U96-107-4 $4^{\mathrm{T}}\left(=\mathrm{IFO} 10899^{\mathrm{T}}\right)$ was isolated in October 1996 from soil in Ban-na, Ishigaki Island, Japan, and strain Yk-305a2 (=IFO 1883) was isolated in 1975 from soil in Yaku Island, Japan. Cultures of the type strain U96-107-4 ${ }^{\mathrm{T}}$ (= IFO $10899^{\mathrm{T}}$ ) have been deposited in the culture collection of the Institute for Fermentation, Osaka, Japan.

\section{Latin diagnosis of Tetrapisispora arboricola sp. nov.}

In medio liquid cum glucoso, peptono et extracto levidinis post dies 2 ad $24^{\circ} \mathrm{C}$, cellulae ovoideae vel sphaericae, $2.0-4.0 \times 2 \cdot 0-6.0 \mu \mathrm{m}$, singulae aut binae, per gemmationem multilateralem reproducentes. Cultura in agaro cum glucoso, peptono et extracto levidinis post unum mensem ad $24^{\circ} \mathrm{C}$, butyrosa, glabra, nitida et eburnea. Pseudomycelium nullum. Asci per transformationem cellularum vegetativarum diploidearum, 1-4 ascosporas continentes. Ascosporae ovoideae vel reniformes. Asci non rumpuntur.

Glucosum et galactosum fermentantur, at non L- 
sorbosum, maltosum, sucrosum, cellobiosum, trehalosum, lactosum, mellibiosum, raffinosum nec D-xylosum. Glucosum, galactosum, trehalosum et glycerolum assimilantur, at non L-sorbosum, maltosum, sucrosum, cellobiosum, lactosum, melibiosum, raffinosum, melezitosum, inulinum, amylum, D-xylosum, L-arabinosum, D-arabinosum, D-ribosum, L-rhamnosum, ethanolum, erythritolum, ribitolum, galactitolum, D-mannitolum, Dglucitolum, $\alpha$-methyl D-glucosidum, salicinum, Dglucono-1,5-lactonum, acidum lacticum, acidium succinicum, acidium citricum, inositolum, gluconicum, glucosaminum nec arbutinum.

Nitras kalicus, ethylaminum, lysinum nec cadaverinum non assimilantur. Non crescit sine vitaminis. Non crescere potest in $0.01 \%$ cycloheximido. Exiguum crescere potest in $10 \% \mathrm{NaCl} / 5 \%$ glucoso. Augmentum in $34{ }^{\circ} \mathrm{C}$. Diazonium caerulian $\mathrm{B}$ non respondens. $\mathrm{G}+\mathrm{C}$ acidi deoxyribonucleati $31 \mathrm{~mol} \%$ per HPLC. Systema coenzymatis Q-6 adest.

Typus depositus in collectione Institute for Fermentation, Osaka, Japonia (IFO 10925 $5^{\mathrm{T}}$.

\section{Description of Tetrapisispora arboricola sp. nov.}

Tetrapisispora arboricola (ar.bo.ri'co.la. L. fem. n. arboricola tree-dweller, relating to the original isolation of the species).

In YPD broth, after $48 \mathrm{~h}$ growth at $24{ }^{\circ} \mathrm{C}$, the cells were ovoid to spherical and $2 \cdot 0-4.0 \times 2 \cdot 0-6 \cdot 0 \mu \mathrm{m}$, single or in pairs. Sediment is present. Budding is multipolar. After 1 month at $24^{\circ} \mathrm{C}$, YPD agar streak culture is butyrous, smooth, glistening and creamcoloured. Branching hyphae or pseudohyphae are not formed in Dalmau plate cultures on cornmeal agar. Oval asci containing 1 -4 ovoid to reniform ascospores are formed directly from diploid cells after incubation for 1 week at $24^{\circ} \mathrm{C}$ on potassium acetate agar, YM agar and cornmeal agar. Asci are persistent.

Glucose and galactose are fermented. L-Sorbose, maltose, sucrose, cellobiose, trehalose, lactose, melibiose, raffinose and D-xylose are not fermented. The following carbon compounds are assimilated: glucose, galactose, trehalose and glycerol. No growth occurs on L-sorbose, maltose, sucrose, cellobiose, lactose, melibiose, raffinose, melezitose, inulin, starch, D-xylose, L-arabinose, D-arabinose, D-ribose, L-rhamnose, ethanol, erythritol, ribitol, galactitol, D-mannitol, D-glucitol, $\alpha$-methyl D-glucoside, salicin, D-glucono1,5-lactone, DL-lactate, succinate, citrate, inositol, gluconate, glucosamine or arbutin. The following nitrogen compounds are not assimilated: nitrate, ethylamine, lysine and cadaverine. No growth occurs in vitamin-free medium. No growth occurs in the presence of $0.01 \%$ cycloheximide. Slow growth occurs in the presence on $10 \% \mathrm{NaCl} / 5 \%$ glucose. Growth occurs at $34^{\circ} \mathrm{C}$, but not at $37^{\circ} \mathrm{C}$. The diazonium blue $B$ reaction is negative. Production of starch-like substances is negative. $\mathrm{G}+\mathrm{C}$ content of DNA is $31 \mathrm{~mol} \%$ by HPLC. Ubiquinone system is Q-6.
Strains U97-412-1 ${ }^{\mathrm{T}}\left(=\mathrm{IFO} 10925^{\mathrm{T}}\right)$ and U97-412-3 (= IFO 10926), from flowers of Elaeocarpus decipiens, U97-436-2 (= IFO 10927), from a leaf of Bruguiera conjugata, and U97-437-2 (= IFO 10928), from a leaf of Rhizophora mucronata, were isolated in July 1997 in a mangrove area of Iriomote Island, Japan. Cultures of the type strain U97-412-1 ${ }^{\mathrm{T}}\left(=\mathrm{IFO} 10925^{\mathrm{T}}\right.$ ) have been deposited in the culture collection of the Institute for Fermentation, Osaka, Japan.

\section{DISCUSSION}

The Nansei Islands stretch for about $1200 \mathrm{~km}$ between the Japanese mainland in the temperate zone and Taiwan in the subtropical zone. They are the habitat of many native animals and plants and are often thought of as the 'Oriental Galapagos'. The three new species had not been isolated from any other place surveyed on the Japanese mainland. The fact that strains related to $T$. phaffii $(=K$. phaffii $)$ were isolated from Ishigaki and Iriomote Islands, located in the south of the Nansei Islands, and Yaku Island, lying about $1200 \mathrm{~km}$ to the north, suggests that these strains may be distributed widely throughout the Nansei Islands.

In this study, new species were isolated from normal substrates by enrichment culture using screw-cap culture tubes, suggesting that this method is suitable for the isolation of fermenting yeasts.

Vaughan-Martini et al. (1993) reported that low DNA relatedness corresponds to completely different chromosomal patterns in the case of Saccharomyces. They also reported that similar but not identical karyotypes did not guarantee conspecificity. However, DNA-DNA hybridization tests in this study showed that strains with similar but not identical karyotypes were conspecific: U96-107-4 ${ }^{\mathrm{T}}$ and Yk-305a2, and U97412-1 ${ }^{\mathrm{T}}$, U97-412-3, U97-436-2 and U97-437-2. The $18 \mathrm{~S}$ rDNA sequences showed no more than one substitution between conspecific strains U96-107-4 and $\mathrm{Yk}-305 \mathrm{a} 2$, and more than two substitutions were found between strains of different species (Table 3).

$T$. phaffii $(=K$. phaffi $)$ and the three new species were similar in their morphological and physiological characters, but differed in the type of ascus deliquescence; in T. phaffii $\left(=K\right.$. phaffii) and U97-101-2 ${ }^{\mathrm{T}}$ (T. iriomotensis), asci ruptured soon after formation; in the other six strains ( $T$. nanseieis, $T$. arboricola), asci were persistent. In 1965, van der Walt combined Kluyveromyces species with others on the basis that ascus deliquescence correlated better than spore number with other characteristics of the species (van der Walt, 1965). On this basis, U97-101-2 ${ }^{\mathrm{T}}$ belongs to the genus Kluyveromyces and the other isolates to a different genus. However, $T$. phaffii $(=K$. phaffii $)$ and the three new species displayed a particularly close genealogical affinity with each other, and the $T$. phaffi $(=K$. phaffii $)$ cluster exhibited no specific association with any other species examined (Fig. 3).

On the basis of polyphasic taxonomic data presented 
in this study, $K$. phaffii and three new species clearly represent a novel taxonomic group equivalent to a new genus, Tetrapisispora gen. nov.

A new proposal to rearrange the genus Kluyveromyces came from Naumov $(1986,1987)$, who reviewed some of the evidence published to that point and advocated (i) confining Kluyveromyces to the multispored species, (ii) reinstating the name Zygofabospora for haplontic, four-spored species and (iii) creating a third genus for diplontic species, which at the time included only $K$. phaffii. $T$. phaffii $(=K$. phaffii $)$ was originally described as Fabospora phaffii by van der Walt (1963). Therefore, the third genus might be the genus Fabospora, which was defined by Kudrjanzev (1960) as diplontic, fourspored species in which the asci rupture on maturation. However, the new species, $T$. nanseiensis and $T$. arboricola, asci of which were persistent, were not assigned to the genus Fabospora. The type species of genus Fabospora was not defined (Kudrjanzev, 1960); furthermore, all the other species, Fabospora macedoniensis, Fabospora fragilis and Fabospora marxiana, have been classified into Kluyveromyces marxianus (Lachance, 1998). To prevent taxonomic confusion, Fabospora should not be adopted as the genus of $T$. phaffii and three new species.

The results of mating studies (Johannsen, 1980), DNA reassociation analysis (Fuson et al., 1987), rDNA restriction mapping (Shen et al., 1994) and the rDNA analysis (Fig. 3) likewise indicate that $K$. blattae is distinct from other species of Kluyveromyces. Cai et al. (1996) reported that the $18 \mathrm{~S}$ rDNA sequence identity between $T$. phaffii $(=K$. phaffii) and $K$. blattae was $96.0 \%$; nevertheless, $T$. phaffii $(=K$. phaffii $)$ was most similar to K. yarrowii $(97.0 \%)$ and K. blattae was most similar to Zygosaccharomyces florentinus $(96.5 \%)$. The aforementioned results showed that $T$. phaffii $(=K$. phaffii) had a loose association with $K$. blattae. The loose association of $K$. blattae with the Tetrapisispora cluster was not statistically significant, as shown by the relatively low bootstrap value of $54.6 \%$ omitted from Fig. 3. In terms of morphological characters, K. blattae is also only distantly related to the genus Tetrapisispora. Therefore, $K$. blattae should not be included in the genus Tetrapisispora.

\section{ACKNOWLEDGEMENTS}

This work was supported by a Grant-in-Aid (No. 08660405) for Scientific Research from the ministry of Education, Science, Sports and Culture of Japan.

\section{REFERENCES}

Cai, J., Roberts, I. N. \& Collins, M. D. (1996). Phylogenetic relationships among members of the ascomycetous yeast genera Brettanomyces, Debaryomyces, Dekkera, and Kluyveromyces deduced by small-subunit rRNA gene sequences. Int $J$ Syst Bacteriol 46, 542-549.

Carle, G. F. \& Olson, M. V. (1985). An electrophoretic karyotype for yeast. Proc Natl Acad Sci USA 82, 3756-3760.

Felsenstein, J. (1985). Confidence limits on phylogenies: an approach using the bootstrap. Evolution 39, 783-791.
Fuson, G. B., Presley, H. L. \& Phaff, H. J. (1987). Deoxyribonucleic acid base sequence relatedness among members of the yeast genus Kluyveromyces. Int J Syst Bacteriol 37, 371-379.

Holm, C., Meeks-Wagner, D. W., Fangman, W. L. \& Botstein, D. (1986). A rapid, efficient method for isolating DNA from yeast. Gene 42, 169-173.

James, S. A., Cai, J., Roberts, I. N. \& Collins, M. D. (1997). A phylogenetic analysis of the genus Saccharomyces based on $18 \mathrm{~S}$ rRNA gene sequences: description of Saccharomyces kunashirensis sp. nov. and Saccharomyces martiniae sp. nov. Int $J$ Syst Bacteriol 47, 453-460.

Johannsen, E. (1980). Hybridization studies within the genus Kluyveromyces van der Walt emend. van der Walt. Antonie Leeuwenhoek 46, 177-189.

Kaneko, Y. \& Banno, I. (1991). Re-examination of Saccharomyces bayanus strains by DNA-DNA hybridization and electrophoretic karyotyping. Inst Ferment Res Commun 15, 30 41.

Kimura, M. (1980). A simple method for estimating evolutionary rates of base substitutions through comparative studies of nucleotide sequences. $J$ Mol Evol 16, 111-120.

Kock, J. L. F., Coetzee, D. J. \& Pretorius, G. H. J. (1988). The phylogenetic development of species representing the genus Kluyveromyces. Syst Appl Microbiol 10, 293-296.

Kudrjanzev, V.I. (1960). Lateinische diagnosen der beschriebenen taxonomischen gruppen. In Die Systematic der Hefen, p. 275. Berlin: Akademie Verlag.

Lachance, M. A. (1998). Kluyveromyces van der Walt emend. van der Walt. In The Yeasts, a Taxonomic Study, 4th edn, pp. 227-247. Edited by C. P. Kurtzman \& J. W. Fell. Amsterdam: Elsevier.

Molnár, O., Prillinger, H., Lopandic, K., Weigang, F. \& Staudacher, E. (1996). Analysis of coenzyme $Q$ systems, monosaccharide patterns of purified cell walls, and RAPD-PCR patterns in the genus Kluyveromyces. Antonie Leeuwenhoek 70, 67-78.

Nakagiri, A. (1991). Coenzyme Q systems in the genus Corollospora and allied marine fungi. Inst Ferment Res Commun 15, 97-104

Naumov, G. I. (1986). Genosystematics of yeasts of the genus Zygofabospora Kudriavzev emend. G. Naumov. Mol Genet Mikrobiol Virusol 5, 10-13 (in Russian).

Naumov, G. I. (1987). Nomenclature of a yeast genus, Zygofabospora Kudriavzev emend. G. Naumov. Mikol Fitopatol 21, 134-140 (in Russian).

Poncet, S. (1973). Taxonomie numérrique du genre Kluvveromyces. Mycopathol Mycol Appl 51, 267-281.

Saiki, R. K., Gelfand, D. H., Stoffel, S., Scharf, S. J., Higuchi, R., Horn, G. T., Mullis, K. B. \& Erlich, H. A. (1988). Primer-directed enzymatic amplification of DNA with a thermostable DNA polymerase. Science $\mathbf{2 3 9}$, 487-491.

Saitou, N. \& Nei, M. (1987). The neighbor-joining method: a new method for reconstructing phylogenetic trees. Mol Biol Evol 4, 406-425.

Shen, P., Jong, S.C. \& Molina, F. I. (1994). Analysis of ribosomal DNA restriction patterns in the genus Kluyveromyces. Antonie Leeuwenhoek 65, 99-105.

Tamaoka, J. \& Komagata, K. (1984). Determination of DNA base composition by reversed-phase high-performance liquid chromatography. FEMS Microbiol Lett 25, 125-128.

Vaughan-Martini, A. \& Martini, A. (1987). Taxonomic revision of the yeast genus Kluyveromyces by nuclear deoxyribonucleic acid reassociation. Int J Syst Bacteriol 37, 380-385. 
Vaughan-Martini, A., Martini, A. \& Cardinali, G. (1993). Electrophoretic karyotyping as a taxonomic tool in the genus Saccharomyces. Antonie Leeuwenhoek 63, 145-156.

van der Walt, J. P. (1963). Fabospora phaffii sp. n. Antonie Leeuwenhoek 29, 319-322.

van der Walt, J.P. (1965). The emendation of the genus Kluyveromyces v. d. Walt. Antonie Leeuwenhoek 31, 341-348. van der Walt, J.P. (1971). New combinations in the genera Brettanomyces, Kluyveromyces, Lodderomyces and Wingea. Bothalia 10, 417-418.

van der Walt, J. P. \& Yarrow, D. (1984). Methods for isolation, maintenance, classification and identification of yeasts. In The Yeasts, a Taxonomic Study, 3rd edn, pp. 76-97. Edited by N. J. W. Kreger-van Rij. Amsterdam: Elsevier. 